\title{
Limitation of usage of PicoGreen dye in quantitative assays of double- stranded DNA in the presence of intercalating compounds
}

\author{
Marcin Koba ${ }^{1,2 凶}$, Alicja Szostek ${ }^{1}$, and Jerzy Konopa ${ }^{1}$ \\ ${ }^{1}$ Department of Pharmaceutical Technology and Biochemistry, Gdańsk University of Technology, Gdańsk, \\ Poland; 'Department of Drug Chemistry, Faculty of Pharmacy, Collegium Medicum of Nicolaus Copernicus \\ University, Bydgoszcz, Poland
}

Received: 09 September, 2007; revised: 20 November, 2007; accepted: 09 December, 2007 available on-line: 10 December, 2007

\begin{abstract}
PicoGreen is a very sensitive fluorescent dye for quantitative assays of double-stranded DNA (dsDNA) in solution and is used in several analytical protocols in which sensitive and precise DNA detection is needed, also for examination of drug-DNA interactions. The data shown in this paper indicate that compounds intercalating to DNA influence the applicability of PicoGreen dye for quantitative measurements of dsDNA, and for this reason PicoGreen dye is not suitable for examination of drug-DNA interactions, especially interstrand DNA crosslinks.
\end{abstract}

Keywords: PicoGreen dye, quantitative assay, double-stranded DNA, drug-DNA binding, interstrand DNA cross-link determination

\section{INTRODUCTION}

PicoGreen is a very sensitive fluorescent dye with very low own fluorescence used for quantitative assays of double-stranded DNA (dsDNA) in solution. This dye enables the detection of as little as $25 \mathrm{pg} / \mathrm{ml}$ of dsDNA (Singer et al., 1997). PicoGreen is commonly used to quantitate PCR amplification yields (Romppanen et al., 2000), as a fluorescent probe (Ashley et al., 2004), for detection of nucleic acids in gels and for DNA labeling in various microscopic protocols (Kral et al., 2005; Kasaisavee et al., 2006; Gagna et al., 2007), in assays of enzymatic activities (Choi \& Szoka, 2000; Tolun \& Myers, 2003), adenovirus DNA amount (Murakami \& McCaman, 1999) or DNA quantitation for capillary electrophoresis (Guillo et al., 2006) and several other analytical protocols in which sensitive dsDNA detection is needed, e.g. examination of drug-DNA interactions. However, as we show in this publication, there are same limitations to the use of PicoGreen for the determination of dsDNA.

\section{MATERIALS AND METHODS}

Chemicals. Sodium dodecylsulfate (SDS) was from Serva (Heidelberg, Germany); $\mathrm{NaClO}_{4}$ was from Fluka (Sigma-Aldrich, Poland); 2,5-diphenyloxazole (PPO) and 1,4-bis-(5-phenyl-2-oxazolyl)-benzene (POPOP) were from Merck (Darmstadt, Germany); methyl $\left[{ }^{14} \mathrm{C}\right]$ thymidine was from Amersham International (Amersham, UK); PicoGreen was from Molecular Probes (Eugene, OR, USA); mitomycin C, mitoxantrone and other reagents were from SigmaAldrich (Poznań, Poland). All reagents used were at least of the analytical grade. Ultra pure water (18 $\mathrm{M} \Omega$ ) was used in all experiments.

Cell culture and media. HL60 (human myeloblastic leukemia) cells were cultivated at $37^{\circ} \mathrm{C}$ in

$\square$ Corresponding author: Dr. Marcin Koba, Department of Drug Chemistry Faculty of Pharmacy, Collegium Medicum of Nicolaus Copernicus University, Sklodowskiej-Curie 9, 85-094 Bydgoszcz, Poland; phone/fax: (48) 52585 3532; e-mail: kobamar@wp.pl

Abbreviations: ctDNA, calf thymus DNA; dsDNA, double-stranded DNA; FCR, fraction of crosslinked DNA; MMC, mitomycin C; MTX, mitoxantrone; PBS, phosphate-buffered saline; ssDNA, single-stranded DNA; TCA, trichloroacetic acid. 
$5 \% \mathrm{CO}_{2}$ /air atmosphere in RPMI-1640 medium with $5 \%$ FCS supplemented with $100 \mu \mathrm{g} / \mathrm{ml}$ streptomycin, $100 \mathrm{U} / \mathrm{ml}$ penicillin. The RPMI-1640 medium and fetal calf serum (FCS) were from Gibco Europe Ltd (Paisley, UK); antibiotics were from Sigma-Aldrich (Poznań, Poland); Proteinase $\mathrm{K}$ was from Merck (Darmstadt, Germany); nuclease $S_{1}$ from Fermentas (Vilnius, Lithuania); calf thymus DNA (ctDNA, type II) from Sigma-Aldrich (Poznań, Poland).

Determination of interstrand DNA crosslinks using radiolabeled DNA. Fraction of renatured DNA and percentage of DNA with induced interstrand cross-links were determined using $S_{1}$ nuclease assay as previously described by Składanowski and Konopa (1994). DNA in exponentially growing cells $\left(2 \times 10^{6}\right)$ was labeled by overnight incubation of cells in medium containing $\left[{ }^{3} \mathrm{H}\right]$ thymidine $(0.02$ $\mu \mathrm{Ci} / \mathrm{ml})$. Then, the cells were treated for $3 \mathrm{~h}$ with different concentrations of the drugs studied. After treatment with the compounds the cells were transferred to test tubes and washed with ice-cold PBS twice. After washing the cells were resuspended in $0.1 \mathrm{ml} \mathrm{PBS}$, and mixed with $0.2 \mathrm{ml}$ of lysing solution $(10 \mathrm{mM}$ Tris/ $\mathrm{HCl}, 10 \mathrm{mM}$ EDTA, $10 \mathrm{mM} \mathrm{NaCl}$, $0.5 \%$ SDS, pH 8.0) supplemented with Proteinase $\mathrm{K}$ $(1 \mathrm{mg} / \mathrm{ml})$. After $1 \mathrm{~h}$ at $37^{\circ} \mathrm{C}, 1.8 \mathrm{ml}$ of denaturating solution (5.25 M sodium perchlorate, $1 \mathrm{mM}$ EDTA, $0.2 \% \mathrm{~N}$-lauryl sarcosine, $20 \%$ methanol, $\mathrm{pH} 7.0$ ) was added and incubation was continued for additional $1 \mathrm{~h}$. DNA was denatured by heating at $50^{\circ} \mathrm{C}$ for 30 $\mathrm{min}$, then renatured by rapid dilution with $10 \mathrm{ml}$ of ice-cold zinc buffer $(1 \mathrm{mM}$ zinc acetate, $5 \mathrm{mM}$ sodium acetate, $10 \mathrm{mM} \mathrm{NaCl}, \mathrm{pH} 4.4$ ) and cooling at $-18^{\circ} \mathrm{C}$. The samples were divided into two series, $2 \mathrm{ml}$ each. To one series, nuclease $\mathrm{S}_{1}(200 \mathrm{U} / 15 \mu \mathrm{l})$ was added for $1 \mathrm{~h}$ at $40^{\circ} \mathrm{C}$, while the other series was left at room temperature. Then, the samples were chilled on ice and DNA was precipitated by the addition of cold 15\% TCA. After $30 \mathrm{~min}$, the precipitates were collected onto nitrocellulose filters $(0.45 \mu \mathrm{m})$ (Sartorius, type SM 113) and washed with $10 \%$ TCA and methanol/chloroform $(1: 1, \mathrm{v} / \mathrm{v})$. The filters were dried overnight and their radioactivity was determined in scintillation fluid (4 g PPO, 0.05 g POPOP, 11 toluene) in Beckman LS 3801. The fraction of cross-linked DNA (FCR) was calculated according to the formula:

$F C R[\%]=\frac{F D S_{\text {traat }}-F D S_{\text {conr }} x 100}{1-F D S_{\text {conr }}}$

where FDS is the ratio of radioactivity (dpm) measured in samples treated vs non-treated with nuclease $S_{1}$ and defines the amount of dsDNA from cells treated with a drug $\left(F D S_{\text {treat }}\right)$ and non-treated cells $\left(F D S_{\text {contr }}\right)$.

Fluorimetric determination of interstrand DNA crosslinks using ethidium homodimer. Frac- tions of renatured DNA was determined using ethidium homodimer assay as described previously by Skladanowski et al. (2001). Upon completion of incubation, $2.5 \times 10^{6}$ cells, either control or treated with drugs, were washed twice with ice-cold PBS, resuspended in $0.1 \mathrm{ml} \mathrm{PBS}$, and mixed with $0.3 \mathrm{ml}$ of lysing solution $(50 \mathrm{mM}$ Tris/ $\mathrm{HCl}, 10 \mathrm{mM}$ EDTA, $1 \%$ lauroyl sarcosine, $\mathrm{pH}$ 8.0, supplemented with $0.5 \mathrm{mg} /$ $\mathrm{ml}$ Proteinase $\mathrm{K}$ ) and incubated at $37^{\circ} \mathrm{C}$ for $2 \mathrm{~h}$ with occasional mixing. Following lysis, $3.6 \mathrm{ml}$ of denaturing solution was added (6 M sodium perchlorate, $1 \mathrm{mM}$ EDTA, $0.2 \%$ lauroyl sarcosine, $20 \%$ methanol, $\mathrm{pH}$ 7.0) and mixed thoroughly. The lysates were left at room temp. for $1 \mathrm{~h}$ and divided into 'native' nondenatured and 'denatured' samples (1 $\mathrm{ml}$ each). In the latter, DNA was denatured by heating in a water bath at $50^{\circ} \mathrm{C}$ for $30 \mathrm{~min}$ and renatured by rapid dilution with $5 \mathrm{ml}$ of $0.1 \mathrm{M}$ Tris/ $\mathrm{HCl}$ buffer, $\mathrm{pH}$ 8.0, and cooling in an ice-methanol mixture $\left(-18^{\circ} \mathrm{C}\right)$ for 1 $\mathrm{min}$. The 'native' samples were diluted with $5 \mathrm{ml}$ of Tris/ $\mathrm{HCl}$ buffer without heating, $0.5 \mathrm{ml}$ of each cell lysate was added to $4.5 \mathrm{ml}$ of phosphate buffer (20 $\mathrm{mM}$ potassium phosphate, $0.5 \mathrm{mM}$ EDTA, $\mathrm{pH}$ 11.9), mixed, and diluted 1:1 with ethidium homodimer solution $(0.4 \mathrm{mg} / \mathrm{ml}$ in phosphate buffer). The samples were incubated for $15 \mathrm{~min}$ at room temp. in the dark before fluorescence was measured by a PerkinElmer LS-5B luminescence spectrometer with excitation and emission wavelengths of 540 and $595 \mathrm{~nm}$, respectively. To determine blank fluorescence for all the samples, both 'native' and 'denatured' samples were heated at $95^{\circ} \mathrm{C}$ for $15 \mathrm{~min}$, rapidly quenched in an ice-methanol mixture for $1 \mathrm{~min}$, warmed to room temp., and residual fluorescence was determined as described above. These fluorescence values were subtracted from the total fluorescence of all lysates to obtain values deriving exclusively from the complex of double-stranded DNA and ethidium homodimer. Ratios of fluorescence of 'denatured' and 'native' samples from treated and control cells, $\left(f_{d} /\right.$ $\left.f_{n}\right)_{\text {treat }}$ and $\left(f_{d} / f_{n}\right)_{\text {contr' }}$ expressed as FDS treat and FD$\mathrm{S}_{\text {contr' }}$ respectively, were converted into the percentage of fraction of crosslinked DNA (FCR) according to the formula described above.

Fluorimetric determination of interstrand DNA crosslinks using PicoGreen. This method is a modification of the one described above, with the $S_{1}$ nuclease assay or ethidium homodimer assay for estimation of the fraction of crosslinked DNA replaced by a fluorescence-based assay with PicoGreen. HL60 cells were seeded at $2 \times 10^{6} / 10 \mathrm{ml}$ of RPMI growth medium. The cells were treated for $3 \mathrm{~h}$ with different concentrations of studied drugs and lysis was performed as described above. After lysis, samples were divided into two series and one of them was denaturated and reanturated as described above. Sodium perchlorate was removed from samples by 
A

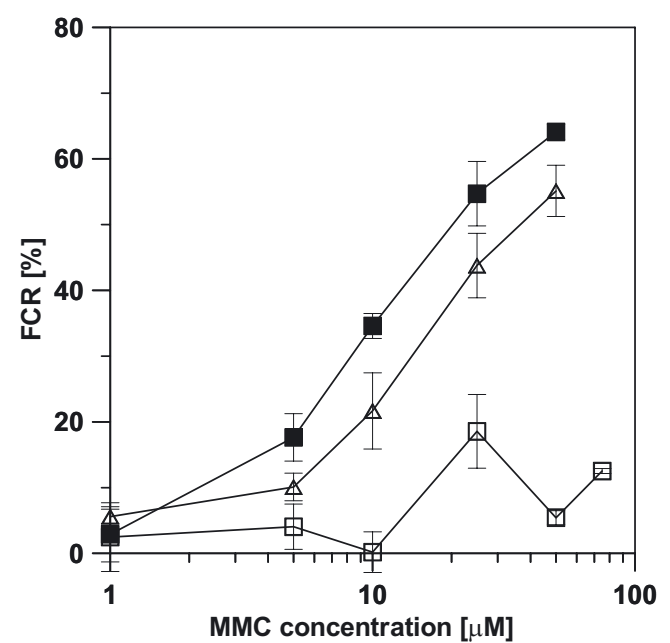

B

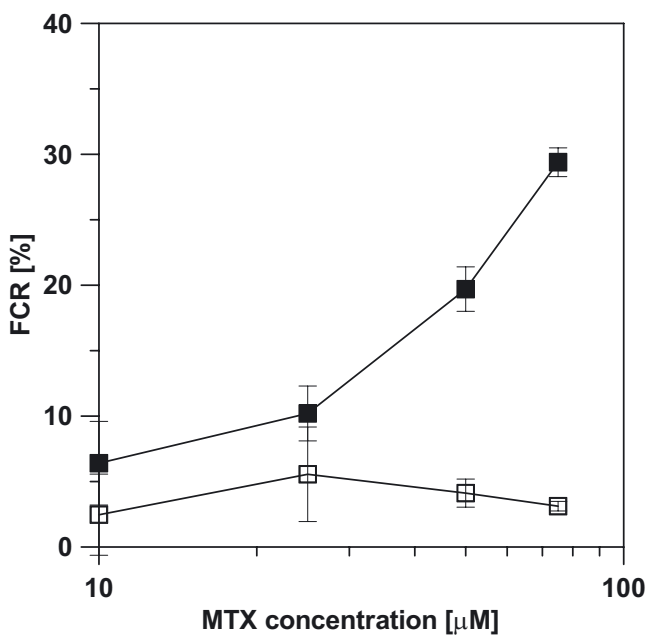

Figure 1. Fraction of crosslinked DNA (FCR) induced by mitomycin C (panel A) or mitoxantrone (panel B) in HL60 cells treated with these drugs for $3 \mathrm{~h}$ and measured using $S_{1}$ nuclease $(\square)$, PicoGreen $(\square)$, or ethidium homodimer $(\Delta)$ methods, respectively. Values are means $( \pm$ S.D.) of three individual experiments.

thin layer dialysis $(3 \times 30 \mathrm{~min})$ against water using Visking dialysis tubes. After dialysis, the samples were diluted $(1: 1)$ with PicoGreen dye solution (from a Molecular Probes kit) and the fluorescence was measured at $\lambda_{\mathrm{ex}}=480 \mathrm{~nm}$ and $\lambda_{\mathrm{em}}=520 \mathrm{~nm}$. Fraction of crosslinked DNA was calculated as described above.

\section{RESULTS AND DISCUSSION}

In our previous experiments in which PicoGreen dye was used to quantitate the level of crosslinked dsDNA, we showed the ability of the minorgroove-binding compound CC-1065 to form covalent interstrand DNA cross-links (Skladanowski et al., 2001). The approach employed was a variant of a method based on DNA denaturation-renaturation phenomena, in which the amount of renaturated dsDNA serving as a measure of cross-linked dsDNA had been estimated either by $S_{1}$ nuclease assay using radiolabeled DNA (Skladanowski \& Konopa, 1994; 2000; Koba \& Konopa, 2007) or fluorimetrically with the ethidium homodimer dye (Skladanowski et al., 2001). Similar levels of interstrand cross-links in DNA of tumor cells treated with CC-1065 were observed independently whether measurement was performed with ethidium homodimer or PicoGreen. However, the variant with ethidium homodimer had some limitations, e.g., ethidium homodimer dye, although it displays high affinity for dsDNA, also binds to proteins, RNA, or even to single-stranded DNA (ssDNA) (Markovits et al., 1979), and hence careful validation of background fluorescence is re-

Table 1. Effects of intercalators on fluorescence intensity of dsDNA : PicoGreen complexes

\begin{tabular}{|c|c|c|c|c|c|}
\hline \multirow{2}{*}{$\begin{array}{l}\text { Drug concentration } \\
{[\mu \mathrm{M}]}\end{array}$} & \multicolumn{5}{|c|}{ aSignal change [\%] } \\
\hline & CC-1065 & Mitomycin C & Mitoxantrone & Actinomycin D & Doxorubicin \\
\hline 0.1 & +0.8 & -12.3 & +4.2 & +14.5 & +1.4 \\
\hline 0.5 & +1.2 & -11.7 & +16.2 & +21.3 & +5.4 \\
\hline 1 & +1.1 & -5.1 & +10.1 & +18.8 & +6.8 \\
\hline 5 & +1.3 & -10.5 & +7.6 & +16.3 & +9.1 \\
\hline 10 & +1.2 & -12.1 & -9.6 & +10.6 & +19.7 \\
\hline 25 & +1.5 & -26.2 & -18.4 & -22.9 & +14.5 \\
\hline 50 & +1.1 & -17.1 & -22.1 & -43.0 & +15.4 \\
\hline 75 & +1.9 & -19.6 & -21.6 & -45.0 & +18.3 \\
\hline
\end{tabular}

aThe drugs were incubated in assay buffer $(10 \mathrm{mM}$ Tris/HCl, $1 \mathrm{mM}$ EDTA, pH 7.5) at the indicated concentrations with PicoGreen dye as recommended by Molecular Probes in the presence of $100 \mathrm{ng} / \mathrm{ml}$ calf thymus DNA. All samples were assayed in a final volume of 400 $\mu 1$ using a Perkin-Elmer LS-5B Luminescence Spectrometer. Samples were excited at $485 \mathrm{~nm}$ and fluorescence intensity was measured at $520 \mathrm{~nm}$. Signal change indicates decrease $(-)$ or increase $(+)$ of fluorescence in the presence of a given drug concentration relative to that in the absence of the drug, taken on $100 \%$. 
quired. In the case of PicoGreen, a very low level of background fluorescence is observed and for this reason it seemed beneficial to use this dye to measure dsDNA to assay interstrand DNA cross-links induced by other DNA cross-linking drugs such as mitomycin C (Dorr et al., 1985) and mitoxantrone (Skladanowski \& Konopa, 2000).

The results obtained with the use of PicoGreen were very surprising and unexpected in the light of those obtained previously for CC-1065 (Skladanowski et al., 2001). In this assay we observed much lower and concentration-independent increase in the fraction of crosslinked DNA (FCR) for mitomycin C (Fig. 1A) and mitoxantrone (Fig. 1B), compared to what was known for these drugs from $S_{1}$ nuclease (Fig. 1A and B) and ethidium homodimer (Fig. 1A) assays.

PicoGreen is a cyanine dye whose detailed structure has been published recently (Zipper et al., 2004). PicoGreen has been shown to intercalate to DNA (Cosa et al., 2001) and a dramatic increase of its fluorescence after binding to dsDNA was observed (Singer et al., 1997). PicoGreen dye, as an intercalating compound, may compete with other intercalators for binding sites, and this could be a potential source of artifacts interfering with fluorescence of dsDNA:PicoGreen complexes changing their signal level. Such competition between polycyclic intercalating compounds for binding sites in DNA is commonly observed and used e.g. in measurements of their relative binding affinity for DNA (Jenkins, 1997). We determined the influence of several intercalating agents on signal intensity of dsDNA:PicoGreen complexes. The results seem to support our presumptions. All intercalating drugs studied (mitomycin C, mitoxantrone, actinomycin D, and doxorubicin) changed the fluorescence intensity of dsDNA: PicoGreen complexes unpredictably, in contrast to the minor-groove-binding compound CC-1065 (Table 1). Moreover, these observations confirmed the data reported for other intercalating compound, such as ethidium monoazide (Hein et al., 2006). This explains why the measurement of interstrand DNA crosslink formation by mitomycin $\mathrm{C}$ and mitoxantrone using PicoGreen dye gave incorrect results. In conclusion, the data shown in this paper indicate the application of PicoGreen dye for quantitative measurements of dsDNA in the presence of compounds that intercalate to DNA is not recommended, especially for examination of interstrand DNA crosslinks and other drug-DNA interactions.

\section{REFERENCES}

Ashley N, Harris D, Poulton J (2004) Exp Cell Res 303: 423446.

Choi SJ, Szoka FC (2000) Anal Biochem 281: 95-97.

Cosa G, Focsaneanu K-S, McLean JRN, McNamee JP, Scaiano JC (2001) Photochem Photobiol 73: 585-599.

Dorr RT, Bowden GT, Alberts DS, Liddil JD (1985) Cancer Res 45: 3510-3516.

Gagna CE, Kuo HR, Chan NJ, Mitacek EJ, Spivak A, Pasquariello TD, Balgobin C, Mukhi R, Lambert WC (2007) J Histochem Cytochem 55: 999-1014.

Guillo C, Ferrance JP, Landers JP (2006) J Chromatogr A 1113: 239-243.

Hein I, Flekna G, Wagner M, Nocker A, Camper AK (2006) Appl Environ Microbiol 72: 6860-6862.

Jenkins TC (1997) Drug-DNA Interaction Protocols. In Methods in Molecular Biology, vol 90, Fox KR, eds, p 195. Humana Press Inc., Totowa.

Kasaisavee V, Suwanarusk R, Nosten F, Kyle DE, Barrends M, Jones J, Price R, Russell B, Lek-Uthai U (2006) Exp Parasitol 114: 34-39.

Koba M, Konopa J (2007) Acta Biochim Polon 54: 297-306.

Kral T, Widerak K, Langner M, Hof M (2005) J Fluoresc 15: 179-183.

Markovits J, Roques BP, LePecq J-B (1979) Anal Biochem 94: 259-264.

Murakami P, McCaman MT (1999) Anal Biochem 274: 283288.

Romppanen EL, Salvolainen K, Mononen I (2000) Anal Biochem 279: 111-114.

Singer VL, Jones LJ, Yue ST, Haugland RP (1997) Anal Biochem 249: 228-238.

Skladanowski A, Konopa J (1994) Biochem Pharmacol 47: 2269-2278.

Skladanowski A, Konopa J (2000) Brit J Cancer 82: 13001304.

Skladanowski A, Koba M, Konopa J (2001) Biochem Pharmacol 61: 67-72.

Tolun G, Myers RS (2003) Nucleic Acids Res 31: e111.

Zipper H, Brunner H, Bernhagen J, Vitzthum F (2004) Nucleic Acids Res 32: e103. 